\title{
HISTORICAL CRISIS AND COSMIC CRISIS IN MARK 13 AND LUCAN'S CIVIL WAR
}

\author{
Edward Adams
}

\section{Summary}

This article suggests that the association of the fall of Jerusalem and the consummation of the age in Mark 13 finds a parallel in the linkage of the collapse of the Roman Republic and the collapse of the cosmos in Lucan's Civil War. Both texts, it is proposed, link a historical catastrophe with the end of the world/age in broadly similar ways.

\section{Introduction}

Of the many thorny exegetical issues in Mark 13, the problem of the link between the destruction of the temple and the end of the world/age is surely the most perplexing. The link is established in the disciples' question of Mark 13:4. In response to Jesus' prediction of the destruction of the temple (13:2), the disciples ask, 'when will this ( $\tau \alpha \hat{v} \tau \alpha)$ be, and what will be the sign that all these things ( $\tau \alpha \hat{v} \tau \alpha \pi \alpha$ ' $v \tau \alpha)$ are about to be accomplished?'. A close connection is here presupposed between the fall of the temple and the city, which took place in 70 C.E., and the end of the age. The disciples, as Mark casts them, assume that the temple's destruction is 'part of a complex of events leading to the End' ${ }^{1}$ ( $c$. Matthew's formulation of the question: 'when will this be, and what will be the sign of your coming and of the end of the age?' Mt. 24:4). In the discourse that follows, which constitutes Jesus' reply to this two-part question, that connection is not disavowed. Statements (apparently) relating to the fall of Jerusalem are interlinked

${ }^{1}$ C.E.B. Cranfield, The Gospel according to Saint Mark (Cambridge: CUP, 1959) 393. 
with statements (apparently) relating to the final consummation. Mark thus leaves it open for his readers to infer that as one of the 'last things', the promised destruction of Jerusalem would lead more or less directly to the coming of the Son of man with its attendant cosmic upheaval and the consummation of the age (Mk. 13:24-26). ${ }^{2}$

Of course, the end of the world did not follow the collapse of Jerusalem in 70 C.E. Thus, as it has turned out, these events, on the face of it, have been tied together mistakenly.

A solution to the problem has recently been offered by N.T. Wright in his monumental work Jesus and the Victory of God. Wright takes the view that the whole of Mark 13 (and its parallels) is about the fall of Jerusalem. ${ }^{3}$ The disciples in their question to Jesus, he argues, were associating the destruction of Jerusalem predicted by Jesus not with the end of the space-time universe, a notion that would have been completely foreign to them, but with 'the end of Israel's period of mourning and exile and the beginning of her freedom and vindication'. ${ }^{4}$ Jesus in his reply confirms this connection: the forthcoming fall of Jerusalem would indeed signal the end of exile and the beginning of a new order. The discourse has specific and exclusive reference to Jerusalem's destruction. There is nothing in it which has to do with the end of the world as this is usually conceived by New Testament scholars. The picture of cosmic upheaval in 13:24-25 takes up language used in the Old Testament with reference to the destruction of Babylon (Is. 14:4, 12-15; 34:3-4; $c f$. Ezk. 32:5-8; Joel 2:10-11, 30-32; 3:14-15) and re-

\footnotetext{
${ }^{2} \mathrm{On}$ the assumption that Mark was writing just before 70 C.E. For the view that Mark's Gospel is to be dated just after the fall of Jerusalem, see M.D. Hooker, The Gospel according to St Mark (London: A \& C Black, 1991) 8.

${ }^{3}$ N.T. Wright, Jesus and the Victory of God: Christian Origins and the Question of God, Volume Two (London: SPCK, 1996) 339-68. While certain details of Wright's approach to Mark 13 are innovative, the broad outline of interpretation he adopts is a long and well-established one; see G.R. Beasley-Murray, Jesus and the Future: An Examination of the Criticism of the Eschatological Discourse, Mark 13 with Special Reference to the Little Apocalypse Theory (London: Macmillan, 1954) 167-71.

${ }^{4}$ Idem, 346.
} 
applies it to Jerusalem. ${ }^{5}$ It no more suggests a literal cosmic catastrophe than Isaiah's prophecy did. The coming of the Son of man spoken of in 13:26 refers not to a future return of Jesus but to 'the defeat of the enemies of the true people of god [sic.], and the vindication of the true people themselves', along with their representative. ${ }^{6}$ Jesus' predictions in Mark 13, on this understanding, were completely fulfilled in the events of 66-70 C.E.

This reading of Mark 13 has the following points among its merits. It does not have to assume that the disciples, as portrayed by Mark (and Matthew) misunderstand the relation between the collapse of Jerusalem and the end of the present age. It provides a consistent account of the events referred to in Mark 13 without having to resort to dual or multiple fulfillments, shortened perspectives, time shifts, time gaps and the like. It does full justice to the claim of Mark 13:30 that, 'this generation will not pass away until all these have taken place [emphases mine]'. And, it saves Mark and Jesus from the embarrassing charge that they were proved wrong when the world did not end as they expected when Jerusalem fell.

Wright's approach, however, is not without its difficulties. In the first place, his interpretation of the Old Testament prophecies lying behind Mark 13:24-25 assumes the conclusions he wishes to reach for the Marcan text ${ }^{7}$ (that the language of cosmic catastrophe and ultimate divine intervention employed by the Old Testament prophets had sole and intended reference to socio-political events within these writers' own horizons; that these prophecies were fulfilled without reservation when the specific historical disasters occurred; that Jewish readers of these texts would have known that the grandiose cosmic language used by the prophets

\footnotetext{
${ }^{5}$ Idem, 354-58.

6Item, 362.

${ }^{7} \mathrm{M}$. Casey (Son of Man: The Interpretation and Influence of Daniel 7 [London: SPCK, 1979] 174) makes this criticism of R.T. France, Jesus and the Old Testament: His Application of the Old Testament to Himself and His Mission (London: Tyndale, 1971) 227-39, who takes a similar (but not identical) line on Mark 13 to Wright.
} 
symbolised only socio-political change). These assumptions are by no means as obvious as Wright suggests.

Second, if the phrase 'the coming of the Son of man' is not a reference to a future parousia of Jesus and Jesus did not himself speak of his own return, as Wright seems to suggest, 8 whence did this cardinal New Testament belief arise? Did it have no foundation in the logia of Jesus? At the very least, Wright's point of view would seem to introduce a sharp disjunction between the eschatological teaching of Jesus and that of Paul.

Third, the problem of the perceived nearness of the end is of course present in other parts of the New Testament. Again, to relieve Mark 13 of the difficulty, it would seem, is only to increase the distance between the outlook of Jesus and that of the earliest church. The latter two points are objections which Wright will certainly have foreseen and will no doubt address in the course of his larger project. ${ }^{9}$ Judgement on his hypothesis must thus, to some extent, be reserved.

As things stand at present, the most satisfactory solution (though by no means a wholly satisfactory solution) to the problem of the close conjunction of the destruction of the temple and the end of the world/age in Mark 13, it seems to me, remains the view that, from Mark's perspective, these are distinct (and distinctly different) events which are eschatologically related but not (or at least, not necessarily) temporally linked. ${ }^{10}$ Within Mark's symbol system and narrative world, the destruction of Jerusalem and the consummation of the world/age are connected in principle. The events are viewed by Mark as conceptually and sequentially linked, irrespective of how close to or distant from each other on the line of time they turn out to lie.

\footnotetext{
${ }^{8} \mathrm{At}$ least, this is what I understand Wright to be saying. See, e.g., Wright, Jesus, 341-42, 345, 360-67, 632, 659-61.

${ }^{9} \mathrm{~A}$ very brief stab at answering these issues is made in his The New Testament and the People of God: Christian Origins and the Question of God, Volume One (London: SPCK, 1991) 459-64. One looks forward to further and fuller clarification.

${ }^{10}$ The time references in the discourse notwithstanding. The ambiguity of the temporal notes is highlighted by T.D. Geddert, Watchwoords: Mark 13 in Markan Eschatology (JSNTSS 26; Sheffield: JSOT, 1989) 223-58.
} 
Advocates of this style of interpretation (which has many variations and nuances) sometimes draw a parallel with Old Testament prophecy. It is a characteristic of Old Testament prophecy, so it is argued, that events, which in reality are far apart, are brought together and placed in close succession. Jesus and Mark simply reflect this 'prophetic perspective'.11

In this article, I want to suggest that an analogue to Mark's linkage of the fall of Jerusalem with the end of the world/age may be found in a Graeco-Roman text written in the same decade as Mark's Gospel and circulating in the same city where Mark may have composed his work.12 Like Mark 13, Lucan's Civil War closely associates a great socio-political catastrophe with the end of the world/age. For Lucan, the historical crisis is the collapse of the Roman Republic.

\section{Lucan: Life and Work ${ }^{13}$}

Marcus Annaeus Lucanus (39-65 C.E.) was born in Cordoba, Spain. His father was a wealthy Roman knight and his uncles were the philosopher Seneca and the proconsul Gallio (the Gallio of Acts 18). Lucan was brought up and educated in Rome. Receiving the standard education of the elite, Lucan studied both rhetoric and philosophy. He studied philosophy under Cornutus who, like Seneca, was one of the leading representatives of Roman Stoicism of the time. In his early twenties, he went to Athens to continue his studies but was soon recalled by Nero to Rome and admitted into the close

\footnotetext{
${ }^{11} \mathrm{On}$ 'prophetic perspective' and its difficulties, see Beasley-Murray, Jesus and the Future, 131-41, and Geddert, Watchwords, 231-35.

$12 \mathrm{On}$ the insecure assumption that the Gospel, as early church tradition suggests, was written in Rome.

${ }^{13}$ For fuller details, see the biographical notes in the introductory sections of the following translations: Lucan, Pharsalia/The Civil War (trans. D. Little; Dunedin: University of Otago, 1989) 1-5; Lucan, Civil War: Translated with Introduction and Notes (trans. S.H. Braund; Oxford: OUP, 1992) xii-xiv; Lucan's Civil War (trans. P.F. Widdows; Bloomington/ Indianapolis: Indiana University, 1988), xi-xii. The main primary source for Lucan's life is Suetonius, Life of Lucan (in his Lives of the Poets). What follows in the next two paragraphs of the main text of this article is summarised from the above.
} 
circle of the emperor. At the first Neronian Games in 60 C.E., Lucan won a poetic competition. The emperor made Lucan augor and quaestor, and for a while greatly admired his poetic abilities. At around 62 or 63 C.E., Lucan published three books of his epic, the Civil War. Nero's favour toward Lucan, however, was short-lived. The emperor's admiration soon turned to enmity as, so it would seem, he became increasingly jealous of Lucan's poetic successes. In 64 C.E., Nero banned Lucan from giving public readings of his poetry and from appearing in the law courts. At the beginning of 65 C.E., a disillusioned Lucan joined the conspiracy of Piso to assassinate Nero. The plot was uncovered and the conspirators and those connected with them were either executed or compelled to take their own lives. Despite his pleas, Lucan was forced to commit suicide (as were his father and his uncles, Seneca and Gallio). He was 25 years old.

Despite his short life, Lucan wrote prolifically, though the majority of his writings are lost. The ten books of the epic poem on the Civil War, the most substantial of his writings to have survived, were his major work. ${ }^{14}$ It remains incomplete, the most probable explanation for which is that it was interrupted by his untimely death.

\section{Lucan's Civil War}

The Civil War recounts the events of the war between Caesar and Pompey that brought the Roman Republic to an end. The epic begins with Caesar's crossing of the river Rubicon into Italy in 49 B.C.E. It leads up to and includes the fateful and decisive battle of Pharsalus in 48 B.C.E. where Caesar defeated Pompey. It breaks off abruptly with Caesar at war in Egypt. Lucan probably intended to continue his narrative at least until

\footnotetext{
${ }^{14}$ The work has survived with alternative titles, De bello civili and the Parsalia. For discussion as to which is original, see F.M. Ahl, Lucan: An Introduction (Ithaca: Cornell University, 1976) 326-32; Braund, Civil War, xxxviii-xxxix.
} 
the suicide of Cato following the battle of Thapsus in 46 B.C.E. 15

Lucan was dependent on existing historical sources for his narrative, particularly Livy's (now lost) account of the war and Caesar's own description of events. It was not Lucan's intention, though, to write a straightforward historical report. Following the conventions of an epic poem, Lucan felt free to use his imagination and depart from his sources where necessary, omitting and recasting some historical incidents and completely inventing others. ${ }^{16}$

The civil war is narrated as a complete disaster for Rome and Italy. It led to the destruction of the Republic and the loss of political freedom for the people. Caesar, the main character in the poem, is the man most responsible for the calamity. He is vilified and demonised by Lucan throughout. Widdows comments: 'On him Lucan lavishes a marvellous extravagance of hatred, mitigated only by touches of grudging admiration for his demoniac energy'.17 Lucan writes with a strong sympathy for the Republic and a hatred of tyranny. ${ }^{18}$

Lucan, reflecting Roman sensibilities, also writes with a strong repugnance of civil war. ${ }^{19}$ Civil war is more destructive and serious than any other kind of conflict because it divides a society and breaks civil bonds. What is worse, civil war involves a breach of family ties. ${ }^{20}$ Kin opposes kin (Civ. War 1:4). ${ }^{21}$ Thus, civil warfare is a heinous and detestable sin, the worst of all crimes (Civ. War 2:286).

\footnotetext{
15 On the intended scope of the work, see Braund, Civil War, xxxvii-xxxviii. ${ }^{16}$ Braund, Civil War, xx. Most notable among his innovations is his placing of Cicero in Pompey's camp on the eve of the battle of Pharsalus. Cicero missed the battle due to illness (Plutarch, Cicero, 39).

17Widdows, Civil War, xix.

${ }^{18}$ Though his political outlook rests uneasily with his enthusiastic praise for Nero at the start of the poem.

${ }^{19}$ M. Lapidge, 'Lucan's Imagery of Cosmic Dissolution', Hermes 107 (1979) 344-70, 359; Little, Civil War, 20.

${ }^{20}$ Caesar and Pompey were related through marriage.

${ }^{21} \mathrm{We}$ can thus imagine the reaction of Roman readers to the words of Mk. 13:12.
} 


\section{Lucan's Stoicism}

Lucan's thinking was clearly shaped by Stoicism, a philosophy which was highly popular at the time in Rome. As well as his tutor Cornutus, he was no doubt also strongly influenced by his uncle, Seneca. Lucan's work shows definite familiarity with Seneca's On Benefits and Natural Questions.22

Lucan's Stoicism is prominent throughout the poem. ${ }^{23}$ It is seen, for example, in his setting aside of the epic convention of attributing human actions and affairs to the intervention of the gods: the customary divine machinations are replaced by the concepts of Fate and Fortune. It is visible in his characterisation of Cato, who is presented as the archetypal Stoic wise man. ${ }^{24}$ And it is evident in his cosmology. ${ }^{25}$

Lucan holds to the Stoic doctrine of cosmic conflagration or ekpurosis. ${ }^{26}$ The theory adopts a cyclic view of the universe. A world-cycle begins and ends in a conflagration (ekpurosis) when the universe is at a state of absolute fire. A new cycle begins when the primal fire cools to air, then moisture and then the elements of which the world is composed. A world-cycle ends when the cosmos returns to its original fiery state.

The doctrine is expressed by Lucan at the beginning of Book Two of his epic, where he reflects on how it is that human beings have foreknowledge of coming calamities (Civ. War 2:115). ${ }^{27}$ Either portents of disaster are mere coincidence, or (as he believes) all events are causally linked.

Perhaps when the Creator first took up his shapeless realm of raw matter after the conflagration had died down, he fixed causes for eternity, binding himself too by his all-

\footnotetext{
22Lapidge, 'Lucan's Imagery', 357; M.P.O. Morford, The Poet Lucan: Studies in Rhetorical Epic (Oxford: OUP, 1967) 37-50.

${ }^{23}$ Braund, Civil War, xxiii-xxv.

${ }^{24}$ Little, Civil War, 39-47.

${ }^{25}$ See M. Lapidge, 'Stoic Cosmology and Romans Literature, First to Third Centuries A.D.', ANRW 36.3 (1989) 1379-429, 1405-09.

26 On which see D.E. Hahm, The Origins of Stoic Cosmology (Columbus: Ohio State University, 1976) 185-99.

27See Lapidge, 'Stoic Cosmology', 1407.
} 
controlling law, and with the immovable boundary of destiny arranged the universe to introduce prescribed ages $(2: 7-10) \cdot{ }^{28}$

When the new universe is formed after the conflagration subsides, a chain of causes is programmed into it. It is this causal linkage of events which makes foreknowledge possible.

As we will see, Lucan makes reference or allusion to the destruction of the world at the end of the cosmic cycle at various points in his narrative. Lucan's understanding and depiction of the cosmic disaster is substantially derived from Seneca. According to Seneca, the great disaster may be caused by either conflagration or deluge. ${ }^{29}$ This is thus a watery ekpurosis (if this is not a contradiction in terms) as well as a fiery one.

\section{The Collapse of Rome and the Collapse of the Cosmos}

There are four places in the Civil War where the destruction of Rome is directly and explicitly associated with the end of the universe. The first passage is 1:67-80, at the outset of poem. Having announced his topic and praised Nero, Lucan is led to reflect on the causes of the events he is about to describe (1:67$182)$, to ask 'what drove a maddened people to war... what cast out peace from the world?' (1:68-9). He considers various causes including: the concentration of power in three individuals (the first triumvirate, Caesar, Pompey and Crassus), rivalry between Caesar and Pompey and the moral corruption of the Roman people by prosperity. The first and main cause, though, is fate. It was the 'envious chain of destiny' which determined that Rome should collapse. The same force will one day cause the universe to dissolve. Lucan writes:

So, when the final hour brings to an end the long ages of the universe, its structure dissolved, reverting to primeval

${ }^{28}$ The translation followed throughout is that of Braund. I have also followed Braund's line numbering.

${ }^{29}$ Seneca, Natural Questions 3.28.7. 
chaos, then fiery stars will plunge into the sea, the earth will be unwilling to stretch flat her shores, and will shake the water off, Phoebe will confront her brother and for herself demand the day, resentful of driving her chariot along its slanting orbit, and the whole discordant mechanism of universe torn apart will disrupt its own laws (1:72-80). 30

And so it is that 'Mighty structures collapse on to themselves' $(1: 81)$. The collapse of all great things, including Rome and the universe itself, is determined.

Lucan thus establishes at the beginning of his poem a close connection between the fall of Rome (as he views the end of the Republic) and the end of the world. The shattering of peace when the Republic fell is analogous to the break-up of the universe and its return to chaos at conflagration. The linkage of course serves to make a dramatic point. Lucan could hardly have chosen a more powerful and evocative image with which to convey the calamitous nature of the historical event. The juxtaposition, though, is no superficial one. It is deeply rooted in the conceptual world of the Civil War.

In Lucan's Stoically-informed narrative universe, ${ }^{31}$ the two disasters are connected on three levels. They are connected, firstly, on the level of the chain of fate which binds together every event in the universe. This is the most basic level of linkage, one that posits no specific relation between the two events. They are associated simply because they are part of a continuum of interconnected occurrences. They are linked, secondly, as 'Mighty structures'. As such they fall prey to a particular operation of fate, the process by which all great edifices come to eventual ruin. The third, and perhaps most significant, level of linkage is that of the inherent, causal connection between the social order and the cosmic order. ${ }^{32}$ In Stoic thought, the social order is reflective of the cosmic order and vice versa. Since these spheres are inextricably bound together, disruption of societal order entails the disruption of

\footnotetext{
${ }^{30}$ On the cosmological details, see Lapidge, 'Stoic Cosmology', 360-62.

${ }^{31}$ Lucan is not presenting a conventional Stoic picture of the world, but (for poetic reasons) a somewhat distorted version of it.

32Lapidge, 'Lucan's Imagery', 358-60.
} 
the whole cosmos. For Lucan, there is thus a causal relation between the complete collapse of society and government in the civil war and the collapse of the cosmos at ekpurosis. In Lucan's presentation, therefore, the fall of Rome is not only comparable to the dissolution of the cosmos, the latter is, in some sense, the concomitant and direct consequence of the former. 33

The second place were the events are set in parallel is toward the end of Book One (1:639-72). Caesar has crossed the Rubicon into Italy. The senate has flown from Rome. Portents of disaster occur alarming the people. The astrologer Nigidius Figulus attempts to interpret the omens in the sky. ${ }^{34}$ The message is clear: 'imminent destruction is planned for Rome and humankind' (2:644-45). Figulus speculates on what kind of disaster is planned. Is it to be destruction by water, a cataclysm to rival Deucalion's flood (651-54)? Is it to be a setting ablaze of the world in cosmic conflagration (655-59)? No, what the signs in the sky portend is that 'war's frenzy is upon us', when 'the power of the sword shall overthrow legality by might, and impious crime shall bear the name of heroism, and this madness shall extend for many a year' (1:666-69).

In this passage, as Masters points out, the civil war is presented not just as a disaster on a par with cosmic catastrophe. The cosmic disaster is depicted as 'an alternative preferable to civil war' ${ }^{\prime} 35$

The fall of Rome is likened to the dissolution of the cosmos again at 2:289. With civil war imminent, and the world 'tottering' (2:248), Cato is approached by his nephew Brutus. Brutus advises Cato against opposing Caesar and taking part in a war which constitutes the most detestable of crimes. Cato acknowledges that civil warfare is indeed the greatest of crimes. Yet, he continues:

33Lapidge, 'Lucan's Imagery', 359.

${ }^{34}$ It has been argued that Lucan is here reporting an actual prophecy made by Figulus at the time; see R.J. Getty, 'The Astrology of P. Nigidius Figulus', Classical Quarterly 35 (1941) 17-22.

35J. Masters, Poetry and Civil War in Lucan's Bellum Civile (Cambridge Classical Studies; Cambridge: CUP, 1992) 65. 
Who would wish to watch the stars and universe collapsing, free from fear himself to fold his arms and keep them still when ether rushes from on high and earth shudders beneath the weight of the condensing universe? (2:289-92)

Not even a strict Stoic like Cato can fail be stirred in the face of so great an impending disaster: 'Keep far away this shame, $\mathrm{O}$ gods, that Rome should fall and by her fall rouse up the Dahae and the Getae-and I remain unmoved' (2:295-97).

The comparison is made for the fourth and final time at 7:134-8, at a climactic point in the epic. In Book Seven, Lucan describes the build-up to the battle of Pharsalus, the battle itself and the immediate aftermath. The battle of Pharsalus decided the outcome of the civil war. Effectively, it was the point at which the Republic ceased to be.

The opposing armies converge for battle. With his army poised for combat and restless for action to begin, Pompey gives his consent for the battle to go ahead (7:123). Those eager for warfare go wild with excitement. Many, however, grow pale with the apprehension of death and of coming disaster, knowing 'that the day has come which will establish the destiny of human life forever, that the battle will decide what Rome will be' (7:131-33). Though each man is aware of his own personal danger, his own fate counts as little in comparison with the fate of the whole universe. For

Who would fear for himself if he saw the shore inundated by the deep, or sea-water on the mountain tops, and ether falling toward the earth, and the sun hurled down widespread destruction? (7:135-38)

Again the doom of Rome is compared to the dissolution of the cosmos. It is difficult to know what Lucan's intention is here. Is he depicting the soldiers as actually believing the end of the world to be imminent? Or, Is he rather indicating that the fear which the men now feel at the approach of the great battle to decide the fate of Rome is similar to that which they would feel were the cosmos about to dissolve. The same ambiguity is present in 2:289-92, in the speech of Cato. Such an ambivalence 
only underlines how tightly tied the historical disaster is to the cosmic disaster.

\section{Other References and Allusions to Cosmic Collapse}

There are several other passages in Lucan's Civil War where the great cosmic catastrophe is described or alluded to. These references and echoes serve to keep alive in his readers' minds the parallel between the civil war and the end of the cosmos. ${ }^{36}$

An allusion is made in 4:48-120. It occurs at a key point in the story. Pompey's and Caesar's armies are about to meet for the first time. With the encounter soon to take place, a tremendous flood intervenes, overrunning Caesar's camp. The flood is no ordinary one but is of almost universal proportions. As Morford has shown, Lucan's description of the deluge draws heavily on Seneca's account of the destruction of the world by water in Natural Questions 3:27-30.37 By playing on Seneca's imagery of cosmic catastrophe, Lucan suggests that the flood is an anticipation of the final cataclysm. Such a foreshadowing is for Lucan an apposite precursor to the first engagement of the civil war.

In Book Five, in which Lucan narrates Appius' consultation of the Delphic oracle, the priestess Phemonoe, inspired by Apollo, is given a knowledge of all the events of time, past and future, including the end of the world (5:181).

Later in Book Five, at 5:560-653, a storm scene provides another occasion for the utilisation of the imagery of cosmic destruction. Caesar sets out with Amyclas to sail across the Adriatic. As soon as they set sail, a storm rises. Amyclas urges Caesar to return to shore. Caesar, convinced that the danger would yield to him, insists they sail on. Winds converge from all directions. The seas, carried by the gales, give up their usual positions. The waves, it seems, tower to the stars. Cosmic collapse seems at hand.

36So Lapidge, 'Lucan's Imagery', 359.

37Morford, The Poet Lucan, 45-47. 
Then the gods' dome quakes, the lofty sky thunders, and the heavens suffer with their structure strained. Nature dreaded chaos; it seems the elements have burst their harmonious checks and night again returns to mix the dead with gods. Their one hope of safety is that not yet have they perished in the world's collapse so great (5:632-37).

The final reference to the end of the world in the Civil War occurs after the account of the battle of Pharsalus. When the battle finally ends, Caesar adds to his list of crimes by denying burial or funeral pyre to the dead. But, Lucan remarks, it matters little whether the corpses disintegrate by natural decay or by pyre, since

These people, Caesar, if not consumed by fire now, will be consumed together with earth, together with the waters of the sea. A shared funeral pyre which will mingle stars with dead men's bones awaits the universe (7:812-15).

\section{Lucan and Mark 13: Comparison and Conclusion}

Lucan's Civil War juxtaposes (what is for the writer) a sociopolitical catastrophe, the fall of the Roman Republic, with the cosmic calamity that will end the world. The ruin of the Republic foreshadows the inevitable cosmic ruin. From Book One to Book Seven, Lucan portrays the events of the civil war, culminating in the horrific battle at Pharsalus, as the disintegration of a mighty structure. The references and allusions to cosmic dissolution at various stages in the narrative serve to depict Rome on its 'hurtling course toward destruction' 38 as the mirror image of the universe in its deaththroes.

Several observations can be made about Lucan's linkage of the two disastrous events. Firstly, the association unequivocally establishes the end of the Republic as a disaster of cataclysmic proportions. This is Lucan's personal viewpoint

38Braund, Civil War, xlviii. 
(it is certainly not one shared by Virgil). For him, the fall of the Roman Republic was a tragedy of the greatest depth.

Secondly, the linkage clearly does not amount to an equation and identification of these events, as if to imply that the dreaded cosmic collapse actually took place at the time of the civil war, and is thus no more to be feared. As 7:632-37 makes clear, cosmic dissolution remains a fixed future (and probably, as for most Stoics, a far off) event for Lucan. The fated conflagration was anticipated in the fall of the Republic and was evoked by the events of the civil war, but in no sense was it fulfilled then. The events are strongly related, but they remain distinct and separate.

Thirdly, the doom of the Republic and the end of the world are causally and sequentially linked, but not chronologically related. To some of the characters in the epic, the cosmic disaster may have seemed imminent as the events of the war unfolded, but from Lucan's point of view, it is the inevitability of the end, not the timing of it which is the key issue (after all, a century had passed between the civil war and Lucan's narration of it). The Roman Republic is the last but one of the 'mighty structures' fated to fall. The next in line in the chain of fate is the cosmos itself. When the final cataclysm will happen is neither here nor there for Lucan. What is crucial is that it will happen.

On each of these points, Lucan's association of these events, it seems to me, provides a parallel to Mark's linkage of the ruin of Jerusalem with the coming of the Son of man and the end of the world/age.

For Mark, the connection invests the socio-political event of the fall of Jerusalem, predicted by Jesus, with cosmological and eschatological importance. This is no small point. The analogy marks the event which occurred in 70 C.E. as one of momentous (unparalleled?) theological significance.

Secondly, for Mark as for Lucan, the linkage does not imply that the two great events are one and the same thing. Readers are not expected to infer that the fall of Jerusalem is the parousia of the Son of man and the consummation of the age. The fall of Jerusalem is of a piece with the end-time denouement, but it is not identical to it. 
Thirdly, for Mark as for Lucan, the collocation is not (or not necessarily) a temporal one. The disciples, as portrayed by Mark, may have thought of Jerusalem's destruction and the end of the world/age as closely related in time (as Cato and Pompey's soldiers, as depicted by Lucan, may have thought that the collapse of the cosmos would immediately follow the fall of Rome). The discourse itself, though, does not presume a chronological connection between the two. What is indicated is rather a causal link within a nexus of end-time occurrences. A time gap separating the events is not precluded. ${ }^{39}$

There are, of course, undeniable differences between Lucan and Mark (differences in narrative world, philosophical/ theological outlook, subject matter, chosen genre, etc.). These cannot and should not be underplayed. Both writers, however, share a ancient mindset which can bring together in close relation events distant in time and can see inherent connections between historical events and cosmic occurrences. That such connections appear odd and perplexing to us serves only to underline how far removed our modern western world-views are from ancient ones. 40

${ }^{39}$ Many interpreters see a gap between 13:23 and 13:24; e.g., H. Anderson, The Gospel of Mark (New Century Bible; London: Marshall, Morgan and Scott, 1976) 298; Hooker, Mark, 318; W.L. Lane, The Gospel According to Mark (NICNT; Grand Rapids: Eerdmans, 1974) 474.

40I would like to thank Dr. Douglas Campbell of King's College, London, for his comments on an earlier draft of this article. 